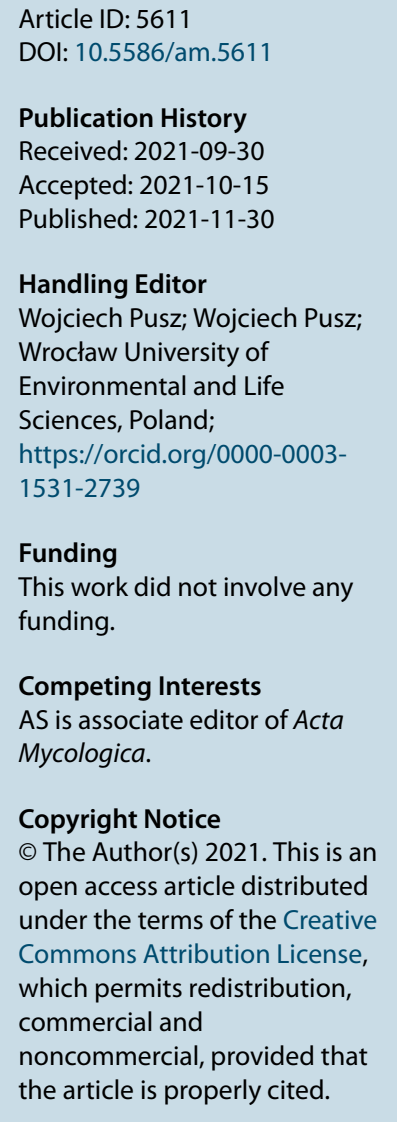

\title{
Professor Andrzej Piotr Grzywacz Dr. h. c. mult.
}

\section{Andrzej Szczepkowski $\odot^{*}$}

Institute of Forest Sciences, Warsaw University of Life Sciences - SGGW, Nowoursynowska 159, 02-776 Warsaw, Poland

* To whom correspondence should be addressed.Email: andrzej_szczepkowski@sggw.edu.pl

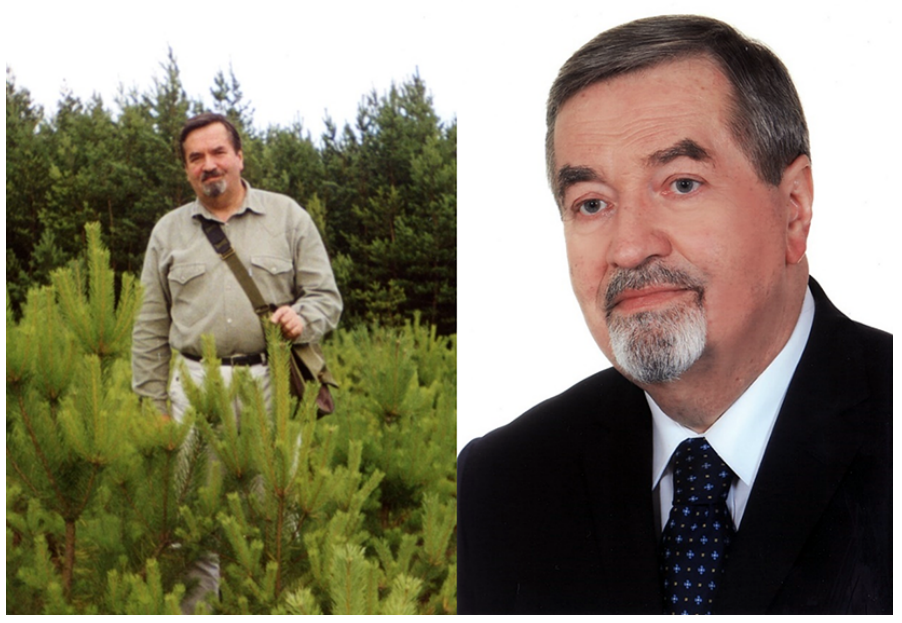

Professor Andrzej P. Grzywacz was born on July 10, 1943, in Toruń, where he completed primary and secondary schooling. During the years 1961-1966, he studied at the Faculty of Forestry of the Warsaw University of Life Sciences (SGGW). His interest in mushrooms was evident since then through his choice of specialization and the title of his master's thesis Grzyby nadrzewne w Leśnictwach Wiartel $i$ Zielone (Puszcza Piska) [Arboreal fungi in the Wiartel and Zielone forest subdistricts (Puszcza Piska Forest)], which he carried out under the supervision of Prof. Jerzy Ważny. Afterwards, he worked in the State Forests in the Forest Districts Smolniki (now Iława) and Olek (now Toruń). In 1972 he completed his doctoral studies (1969-1972) under the supervision of Prof. Jerzy Ważny at the Faculty of Forestry, Warsaw University of Life Sciences (SGGW), and he defended his doctoral dissertation Wpływ przemysłowych zanieczyszczeń powietrza na niektóre patogeniczne grzyby drzew leśnych [The influence of industrial air pollution on selected pathogenic fungi of forest trees]. In 1979, Andrzej Grzywacz was awarded the degree of doctor habilitatus in forest sciences on the basis of his output and the monograph entitled Mechanizm odporności nasion Pinus sylvestris L. na pasożytnicza zgorzel przedwschodowa [Mechanism of resistance of Pinus sylvestris L. seeds to parasitic pre-emergence damping-off]. He started his journey as an associate professor in 1988 and was awarded the title of full professor in 1995.

In 1998, he was elected as a corresponding member, and in 2007, as a full member of the Polish Academy of Sciences. Professor Grzywacz was conferred the title of doctor honoris causa by the August Cieszkowski University of Agriculture (now Poznan University of Life Sciences) (2008), the University of Agriculture in Kraków (2014), and the Wrocław University of Environmental and Life Sciences (2017). From 1969 until his retirement, Prof. A. Grzywacz worked at the Faculty of Forestry of the Warsaw University of Life Sciences. From 1980 to 2012, he served as the head of the Laboratory and later as the head of the Department of Mycology and Forest Phytopathology of the SGGW, which was established on his initiative. He was vice 
dean for teaching (1981-1984), dean of the Faculty of Forestry (1990-1993), and a vice rector for teaching and education at SGGW (1984-1990).

During the course of his extensive professional activity and thematically diversified scientific achievements, several areas that were of interest to him are as follows: forest pathology and mycology, nature protection, policy of the state within the fields of ecology and forestry, development of forest sciences, reform and improvement of forestry studies, education of the society within the field of forestry, and history of forestry. In the fields of phytopathology and mycology, he particularly dealt with the influence of industrial air pollution on forest tree pathogenic fungi, chemical control of seedling damping-off and other diseases in forest nurseries, the mechanism of seed resistance to parasitic pre-emergence damping-off, pathogenic fungi of transplanting stress in older trees, diseases of introduced conifers, provenance resistance to Rhabdocline pseudotsugae of Douglas fir, health of ash trees in urban conditions, ectomycorrhizal fungi for controlled mycorrhization of seedlings in container cultivation, biology and ecology of wood-decaying fungi in the forest and outside, decline of beech and alder stands, chemical wood protection, fungitoxicity of fungicides, legal protection of macrofungi species, monitoring of macrofungi, species diversity of fungi in forest ecosystems, health status of trees, and natural monuments.

Prof. A. Grzywacz has about 500 publications, including 135 original papers published in prestigious Polish (e.g., Acta Societatis Botanicorum Poloniae, Acta Mycologica, Folia Forestalia Polonica, Sylwan) and international (e.g., European Journal of Forest Pathology) journals, scientific monographs and chapters in monographs, 20 books, articles in proceedings of symposia and scientific conferences, extensive review publications, articles in popular scientific and branch press, instruction articles for forest practice and numerous editions of scientific books and materials of scientific symposia, especially those organized by the Polish Forest Society (PTL). He was the founder and principal investigator of 14 research projects commissioned by the Scientific Research Committee (KBN), the State Forests, the Forest Research Institute, and participated in the implementation of seven research projects commissioned by the U.S. Department of Agriculture FG-POL-304, the Polish Academy of Sciences, and the National Fund for Environmental Protection and Water Management. Prof. Grzywacz has written over 110 expert opinions, projects, and studies for forest practice, nature conservation, protection of historical monuments, and the Parliament Office of Analyses.

Furthermore, he has written over 50 prepublication reviews of books and scripts for various publishing houses and over 150 reviews of applications for research projects funded by the State Committee for Scientific Research, Ministry of Science and Higher Education, and the Polish Science Foundation. He has peer-reviewed many manuscripts for Polish and foreign journals and provided his expert opinion on research documentation, applications for scientific prizes, drafts of legislative acts for the Ministry of the Environment, plans for the protection of national parks, and other studies.

Prof. A. Grzywacz has visited numerous scientific institutions in Belarus, Bulgaria, the Czech Republic, Lithuania, Mexico, Germany, Russia, Slovakia, and Hungary. He was a member of Polish delegations at scientific congresses, such as the III Plant Protection Congress (Munich), X World Forestry Congress (Paris), International Union of Forest Research Organizations (IUFRO) 100th Anniversary Congress (Berlin), and IUFRO congresses in Tampere (Finland), Brisbane (Australia), and Seoul (South Korea).

Prof. A. Grzywacz has lectured (both full-time and part-time) postgraduate and doctoral students, not only at the Faculty of Forestry but also at the Biology, Environmental Protection, Tourism and Recreation, Wood Technology (Warsaw University of Life Sciences), and ethnography (on protection of antique wood) departments at the University of Warsaw. He mainly taught forest pathology, nature protection, nature-forest education, and policy of the state within the field of ecology. His wide scientific interests and friendly approach to students and adepts of forest sciences were reflected in numerous works carried out by the students under his supervision. From 1980 to 2021, he supervised 301 master's theses and 96 
engineering theses, and reviewed several hundred diploma theses. These theses concerned mainly phytopathological and mycological issues as well as issues of nature protection and nature-forest education. He was a supervisor of the Phytopathology Section of the Forestry Students Scientific Association and Forestry Students Scientific Association of the SGGW and five student scientific camps. Prof. A. Grzywacz is a well-liked and respected academic teacher with a rare gift of arousing interest in learning and transferring broad knowledge among students. He was the supervisor of 14 doctoral theses. His knowledge, experience, and authority led him to review 37 doctoral theses, 16 habilitation dissertations, and 17 opinions for the title of professor. For the Central Commission for Titles and Degrees, he prepared 26 opinions for professorship applications and 16 opinions for habilitation dissertations. He also prepared three reviews to grant the title of doctor honoris causa. While working as a lecturer at the Warsaw University of Life Sciences, he served as chief nature conservator - Under Secretary of State in the Ministry of Environmental Protection, Natural Resources and Forestry, between 1992 and 1993, where he contributed to the establishment of the Biebrza National Park and the Stołowe Mountains National Park, and from 1995 to 1997 he worked at the National Parks Board, taking care of scientists from all national parks.

Prof. A. Grzywacz greatly values the popularization of science, on which he is working till date. His popular science books are Grzyby i las [Fungi and forest] (1981), Grzyby leśne [Forest mushrooms] (1988, 1990), Grzyby chronione [Protected mushrooms] (1989), Poznajmy las [Let's get to know the forest] (1995), Las twoim bogactwem [Forest your wealth] (2000), „Wiem co zbieram $w$ lesie” [I know what I collect in the forest] (2003; together with P. Staniszewski), Ksiegga lasu [The book of the forest] (2009), Żywot lasu [The life of the forest] (2009), Las tętniacy życiem [Forest teeming with life] (2010), and Drzewa - pomniki przyrody [Trees - Nature monuments] (2013; jointly with J. Pietrzak), and about 275,000 copies of these books have been published. He has published over 150 popular articles in forestry and the nature press. He coauthored three different editions of the Forest Protection Manual $(1998,2004,2012)$. He is the author of 135 mycology entries in the Wielka Encyklopedia Powszechna PWN [Great Universal Encyclopedia PWN] (2001-2005) and 750 entries in the Słownik terminologiczny: leśnictwa, drzewnictwa, ochrony środowiska, łowiectwa i dziedzin pokrewnych [Terminology dictionary: Forestry, wood science, environment protection, hunting and related fields] (1996). He has presented over 280 papers in Poland and abroad at conferences, symposia, and meetings of scientific societies. He has participated in over 120 radio and over 65 television programs of various types. He was a scientific consultant for nine popular science films.

Prof. A. Grzywacz continues to hold a number of academic appointments. He is an elected member of the Warsaw Scientific Society and the Commission of Agricultural, Forestry and Veterinary Sciences of the Polish Academy of Arts and Sciences (Polish Academy of Skills) in Kraków. At the Warsaw University of Life Sciences, he was a member of the Academic Senate and numerous Rector's and Senate committees and an initiator and first editor-in-chief of the university quarterly Agricola. At the Polish Academy of Sciences, he used to hold the posts of chairman of the Division of Agricultural, Forest and Veterinary Sciences, Committee of Forestry Sciences, Scientific Councils of the Botanical Garden in Powsin - Center for the Preservation of Biodiversity of the Polish Academy of Sciences. He also used to hold the position of editor-in-chief of the quarterly Heureka - Problems of the Social Scientific Movement and was a member of the Collegium and the Presidium of the Polish Academy of Sciences, Committee on Nature Conservation of the Polish Academy of Sciences, Scientific Councils of the Institute of Dendrology of the Polish Academy of Sciences in Kórnik. He continues to hold the post of vice chairman of the Council of Scientific Societies at the Polish Academy of Sciences. Since 1979, he has been a member of the Board of the Polish Forest Society, where he also served as a vice president, and from 1997 to 2018 , he was the president of the Society. He is a dignified honorary member and the honorary president of the PTL. With regards to research and teaching, he was chairman of the Scientific Council of the Intercollegiate Methodological Centre of Agricultural Academies, the Scientific and Didactic Team for Forestry and Wood Technology, and the Forestry and Wood 
Section of the Scientific Research Committee; vice chairman of the Central Commission for Title and Scientific Degrees; and member of the General Council for Higher Education. In addition, with regards to the field of forestry and nature protection, he was the chairman of the State Council for Nature Protection, the State Forests Panel, the Scientific Council of the Forest Research Institute, the Scientific Council of the League for Nature Protection, the Main Committee of the Ecological Knowledge Olympiad, the Socio-Scientific Council of the LKP "Puszcza Knyszyńska," and others. He continues to be the chairman or member of editorial and program boards of scientific journals: Acta Mycologica, Folia Forestalia Polonica, Leśne Prace Badawcze, Phytopathologia, Parki Narodowe i Rezerwaty Przyrody, Postepy Nauk Rolniczych, Sylwan, as well as popular science magazines: Las Polski, Poznajmy Las, Przyroda Polska.

Prof. A. Grzywacz has received numerous awards for his scientific and teaching activities, including awards from the Minister of National Education, Minister of Science and Higher Education, Polish Academy of Sciences, Minister of Environment, and rector of the Warsaw University of Life Sciences. He has been awarded the Knight's, Officer's and Commander's Cross of the Order of Polonia Restituta, the Golden Cross of Merit, the Medal of the National Education Commission, the Michał Oczapowski Medal of the Polish Academy of Sciences, Medal for Meritorious Service to National Defense, Medal of the Centenary of Regained Independence, medals of the Office for Veterans and Repressed Persons "Pro Patria" and "Pro Memoria," Medal of the Polish Forest Society "Pro Bono Silvae," and badges "Merited for Forestry and Wood Industry" and "Merited for Environmental Protection and Water Management." He received great appreciation for receiving German foresters award "Lorenz-Wappes-Preis" and the Forest Research Institute medal named after Jan Teodor Hausbrandt. He also holds the Cordell of the Polish Forester and an honorary forester's uniform as well as the Adam Loret Award "for many years of activity for the benefit of forestry and protection of forest nature, forest sciences and for the benefit of the State Forests."

In his life, Prof. Grzywacz diligently follows the words of the Roman philosopher Seneca: "You must live for others if you want to live to benefit yourself." Although Prof. A. Grzywacz retired in 2013, he continues his social and popularization work very actively. He often visits his home Faculty of Forestry at the Warsaw University of Life Sciences (SGGW) and willingly shares his knowledge and experience with younger employees. He also maintains the contact with colleagues from his youth, when he was actively involved in scouting, and he says that the scouts' principles and patterns have significantly shaped his personality and influenced the choice of forestry as a way of life.

Prof. Andrzej Piotr Grzywacz and his wife Maria have two sons (Piotr and Marcin) and are happy grandparents of two granddaughters. 